Bệnh nhân ở các khoảng tuổi nhiễm cả 4 type virus: type 1 (DENV-1), type 2 (DENV-2), type 3 (DENV-3) và type 4 (DENV-4). Trong đó khoảng khoảng tuổi 6-10 chiếm tỉ lệ cao nhất (50,43\% $63,24 \%)$, sau đó là khoảng tuổi 11-15 (23,53\% $38,46 \%)$, và thấp nhất là khoảng tuối $\leq 5$ $(11,11 \%-15,79 \%)$ ở cả 4 type virus, tuy nhiên không có sự khác biệt về tuổi giữa các type virus, với $p=0,1338$. Tỉ lệ nhiễm virus của hai giới là tương đương nhau ở các type virus 1,2 và 4. Ở type 3 tỉ lệ ở nữ $(63,16 \%)$ cao hơn ở nam $(36,84 \%)$, tuy nhiên sự khác biệt giữa hai giới không có ý nghĩa thống kê với $p=0,2513$

\section{TÀI LIỆ THAM KHẢO}

1. Geneva, W.H.O. Fact sheet $\mathbf{N}^{\circ} \mathbf{1 1 7}$, Dengue and dengue hemorrhagic fever, March 2009; Available from: http://www.who.int/ mediacentre/factsheets/fs117/en/, accessed 26 December 2010.
2. Manila, W.H.O.W.P.R.O. Dengue in the Western Pacific. 2010; Available from: http:// www.wpro.who.int/ topics/ dengue/en, accessed 20 December 2010.

3. Huy, R., et al., National dengue surveillance in Cambodia 1980-2008: epidemiological and virological trends and the impact of vector control. Bulletin of the World Health Organization, 2010. 88(9): p. $650-657$.

4. Ooi, E.E., Changing Pattern of Dengue Transmission in Singapore. 2001.

5. Yew, Y.W., et al., Seroepidemiology of dengue virus infection among adults in Singapore. Ann Acad Med Singap, 2009. 38(8): p. 667-75.

6. Guzmán, M.G., et al., Effect of age on outcome of secondary dengue 2 infections. Int J Infect Dis, 2002. 6(2): p. 118-24.

7. Lanciotti R. S., et al., Rapid detection and typing of dengue viruses from clinical samples by using reverse transcriptase-polymerase chain reaction. $]$ Clin Microbiol, 1992. 30(3): p. 545-51.

8. Halsey E. S., et al., Correlation of serotype-specific dengue virus infection with clinical manifestations. PLoS Negl Trop Dis, 2012. 6(5): p. e1638.

\title{
KIẾN THỨC, THÁI ĐỘ VỀ SÀNG LỌC UNG THƯ ĐẠI TRỰC TRÀNG CỦA NGƯỜI DÂN TỪ 50-75 TUỔI TRÊN ĐİA BÀN QUÂ̂N HOÀN KIẾM, HÀ NộI NĂM 2019
}

\section{TÓM TẮT}

Muc tiêu: Mô tả kiến thức, thái đô và nhân thức về rào cản đối với việc chi trả tiền túi để thực hiện sàng loc ung thư đai trực tràng của người dân từ 5075 tuổi trên địa bàn quận Hoàn Kiếm, Hà Nội năm 2019.Phương pháp: Điều tra cắt ngang trên 402 đối tượng 50-75 tuổi đển khám bệnh thông thường tại các phòng khám ngoại trú thuộc Trung tâm y tế quận Hoàn Kiếm từ tháng 1 đến tháng 3/2019. Kết quả và kết luâan: Kiến thức và thái độ ("không nghĩ mình có bệnh" hay "thiếu hiểu biết thông tin khám sàng lọc", "không biết về phương pháp này có thể sàng lọc được" hay "chỉ khi nào có biểu hiện bệnh thì mới đi khám") là yếu tố phổ biến nhất $(43,7 \%)$ mà đối tượng đưa ra trong số các rào cản được đối tượng chỉ ra trong việc chi trả tiền túi để thực hiện xét nghiệm FOBT. Rào cản phổ biến nhất đối với chi trả tiên túi đối với nội soi đại trực tràng liên quan đến sự "sợ hãi khi phát hiện ra bệnh", "sợ đến bệnh viện", "sợ gây mê", "sỡ đưa dụng cụ vào cơ thể gây khó chịu" hay "sợ đau" (34,8\%).

Từ khóa: kiến thức, thái độ, rào cản, sàng lọc ung thư đại trực tràng, nội soi đại trực tràng, FOBT

*Trường Đại học Y tế Công cộng

Chịu trách nhiệm chính: Nguyễn Quỳnh Anh

Email: nqa@huph.edu.vn

Ngày nhận bài: 11.3.2021

Ngày phản biên khoa hoc: 11.5.2021

Ngày duyệt bài: 17.5.2021
Nguyễn Quỳnh Anh*, Nguyễn Thu Hà*

\section{SUMMARY \\ KNOWLEDGE AND ATTITUDES RELATED TO COLORECTAL CANCER SCREENING OF PEOPLE AGED 50-75 YEARS IN HOAN KIEM} DISTRICT, HANOI, 2019

Objective: To describe knowledge, attitudes and perceptions about barriers to colorectal cancer screening of people aged 50-75 years in Hoan Kiem district, Hanoi, 2019.Method: Cross-sectional survey conducted on 402 patients aged $50-75$ years old who went to the outpatient clinics of Hoan Kiem District Medical Center from January to March 2019. Results and conclusion: Knowledge and attitudes ("don't think I have cancer" or "lack of information of screening ", "don't know about the screening techniques " or "only seek treatment when there is a sign of cancer) ") is the most common factor (43.7\%) among the perceived barriers to out of pocket payment to FOBT. The most commom barrier to pay for colonoscopy involve "fear of finding out the disease", "fear of going to the hospital", "fear of anesthesia", "giving the device into the body causing discomfort" or "fear of pain" (34.8\%).

Keywords: knowledge, attitude, percieved barriers, colonoscopy, colorectal cancer screening

\section{I. ĐĂT VẤN ĐỀ}

Tai Viêt Nam, ung thư đai trức tràng (UTĐTT) cùng với các nhóm ung thư khác là một trong 
các nguyên nhân hàng đầu của gánh nặng bệnh tật và tử vong tại Việt $\mathrm{Nam[1].} \mathrm{Sự} \mathrm{gia} \mathrm{tăng} \mathrm{số}$ trường hợp mới mắc ung thư cùng với thực trạng đa số các trường hợp mắc được phát hiện khi đã ở giai đoạn muộn dân đến tỷ lệ tàn tật và tử vong cao và gánh nặng vật chất cũng như tinh thần lớn cho người bệnh, cho hệ thống chăm sóc sức khỏe và toàn xã hội. Vì vậy, việc triển khai thành công các chương trình sàng lọc ung thư ở quy mô cộng đồng đóng vai trò vô cùng quan trọng nhằm giảm nhẹ gánh nặng bệnh tật và tử vong do các bệnh ung thư nói chung và UTĐTT nói riêng.

Sàng lọc UTĐTT sử dụng xét nghiệm xét nghiệm máu ẩn trong phân (FOBT) và sàng lọc UTÐiT với trường hợp kết quả + và với các trường hợp có nguy cơ cao được Bộ $Y$ tế khuyến cáo thực hiện trong Quyết định số 3756/QĐ-BYT ngày $21 / 6 / 2018$. Tuy nhiên đến thời điểm hiện tại, sàng lọc UTĐTT ở Việt Nam mới chỉ diễn ra thí điểm ở một số tỉnh thành phố lớn . Để có thể triển khai được chương trình sàng lọc UTĐTT một cách hiệu quả tại Việt Nam, việc tìm hiểu về kiển thức, thái độ của đối tượng đích về sàng lọc UTĐTT cũng như nhận thức của đối tượng đích về các rào cản đối với sàng lọc UTĐTT sử dụng FOBT và nội soi đại trực tràng là rất quan trọng. Các thông tin này sẽ đóng vai trò hữu ích nhằm cung cấp các bằng chứng để thực hiện các chiến lược truyền thông nhằm tăng cường tỷ lệ tiếp cận với các dịch vụ sàng lọc UTĐTT. Vì lý do đó, bài báo này tập trung vào mục tiêu mô tả kiến thức, thái độ và nhận thức về rào cản đối với sàng lọc UTĐTT của người dân từ 50-75 tuổi trên địa bàn quận Hoàn Kiếm, Hà Nội năm 2019. Bộ số liệu được sử dụng trong nghiên cứu này dựa trên kết quả của cuộc điều tra về Đánh giá mức sẵn sàng chi trả đối với một số can thiệp phát hiện sớm ung thư tai Việt Nam Của tác giả Nguyễn Thu Hà và Nguyển Quỳnh Anh (công bố năm 2020) [2].

\section{II. ĐỐI TƯợNG VÀ PHƯƠNG PHÁP NGHIÊN CỨU}

Tập trung vào các biến số về kiến thức, thái độ, và nhận thức về rào cản của sàng lọc UTĐTT sử dụng FOBT và nội soi đại trực tràng của đối tượng đích được thu thập trong nghiên cứu của tác giả Nguyễn Thu Hà và Nguyễn Quỳnh Anh (2020)[2]. Phương pháp nghiên cứu của nghiên cứu này như sau:

2.1. Thiết kế nghiên cứu: Điêu tra cắt ngang.

2.2. Đối tượng nghiên cứu: Người dân đến khám bệnh tại cơ sở y tế ban đầu trên địa bàn thành phố Hà Nội thỏa mãn các tiêu chuẩn lựa chọn sau: (i) từ 50 đến 75 tuổi; (ii) Chưa từng tham gia sàng lọc UTĐTT; (iii) đồng ý tham gia phỏng vấn và đủ khả năng nghe nói hiểu tiếng Việt, không mắc bệnh tâm thần.

3.3. Thời gian thu thập số liệu: Từ tháng 1 đến tháng 3 năm 2019.

3.4. Địa điểm thu thập số liệu: Các phòng khám thuộc Trung tâm y tế quận Hoàn Kiếm - là cơ sở chăm sóc sức khỏe ban đầu.

3.5. Cỡ mẫu và phương pháp chọn mẫu: Tiến hành phỏng vấn toàn bộ đối tượng thỏa mãn tiêu chí lựa chọn của nghiên cứu đến khám bệnh thông thường tại các phòng khám bệnh ngoại trú thuộc Trung tâm y tế quận Hoàn Kiếm từ tháng 1 đến tháng 3/2019. Tổng cỡ mẫu thu thập được là 402 đối tượng.

3.6. Biến số nghiên cứu: Bô̂ số liệu của nghiên cứu gốc bao gồm nhiều biến số về sẵn sàng chi trả đối với sàng lọc UTĐTT sử dụng xét nghiệm FOBT và nội soi đại trực tràng. Trong bài báo này, chúng tôi tập trung vào các nhóm biến số chính bao gồm: thông tin nhân khẩu-xã hội học, kiến thức và thái độ đối với sàng lọc UTĐTT, yếu tố nguy cơ của UTĐTT và nhận định về rào cản đối với chi trả tiền túi để thực hiện sàng lọc UTĐTT sử dụng FOBT và nội soi đại trực tràng của đối tượng.

3.7. Nhập liệu, quản lý số liệu: Tiến hành nhập vào phần mềm Epi Data 3.1, sau đó làm sạch và được xử lý bằng phần mềm $R$.

3.8. Đạo đức nghiên cứu: Tuân thủ theo đúng các quy định của Hội đồng đạo đức Trường Đại học Y tế công cộng.

\section{KẾT QUẢ NGHIÊN CỨU}

3.1. Thông tin chung về đối tượng. Bảng 1 trình bày thông tin về đặc điểm nhân khẩu - xã hội học, tình trạng tham gia bảo hiểm y tế của đối tượng tham gia nghiên cứu.

Bảng 1: Một số đặc điểm của đôi tượng nghiên cứu

\begin{tabular}{|c|c|c|c|}
\hline & Nam (n=119) & Nũ̃ (n=283) & Chung (n=402) \\
\hline Tuối: Trung bình (SD) & $61,6(6,75)$ & $61,0(6,75)$ & $61,2(6,75)$ \\
\hline \multicolumn{3}{|c|}{ Trình độ học vấn } \\
\hline Chưa tốt nghiệp tiếu học & $12(10,1 \%)$ & $21(7,4 \%)$ & $33(8,2 \%)$ \\
\hline Tốt nghiệp tiếu học & $21(17,6 \%)$ & $88(31,1 \%)$ & $109(27,1 \%)$ \\
\hline Tốt nghiệp THCS & $14(11,8 \%)$ & $21(7,4 \%)$ & $35(8,7 \%)$ \\
\hline
\end{tabular}


TẠP CHÍ Y HỌC VIẸT NAM TẬP 503 - THÁNG 6 - SÓ 1 - 2021

\begin{tabular}{|c|c|c|c|}
\hline Tốt nghiệp THPT & $34(28,6 \%)$ & $61(21,6 \%)$ & $95(23,6 \%)$ \\
\hline Có trình độ chuyên môn & $38(31,9 \%)$ & $92(32,5 \%)$ & $130(32,3 \%)$ \\
\hline \multicolumn{4}{|c|}{ Tình trạng kết hôn } \\
\hline Chưa kết hôn/góa & $2(1,7 \%)$ & $12(4,2 \%)$ & $14(3,5 \%)$ \\
\hline Đã kết hôn & $117(98,3 \%)$ & $271(95,8 \%)$ & $388(96,5 \%)$ \\
\hline \multicolumn{4}{|c|}{ Gia đình thuộc diện hộ nghèo và cận nghèo } \\
\hline Mức sống trung bình trở lên & $94(79,0 \%)$ & $222(78,4 \%)$ & $316(78,6 \%)$ \\
\hline Cận nghèo & $14(11,8 \%)$ & $23(8,1 \%)$ & $49(12,2 \%)$ \\
\hline Nghèo & $11(9,2 \%)$ & $38(13,4 \%)$ & $37(9,2 \%)$ \\
\hline \multicolumn{4}{|c|}{ Tình trạng thè bảo hiếm y tế } \\
\hline Không có BHYT & $9(7,6 \%)$ & $26(9,2 \%)$ & $35(8,7 \%)$ \\
\hline Có BHYT & $110(92,4 \%)$ & $257(90,8 \%)$ & $367(91,3 \%)$ \\
\hline \multicolumn{4}{|c|}{ Lịch sử tham gia sàng lọc UTĐTT } \\
\hline Chưa bao giờ tham gia & $96(80,7 \%)$ & $241(85,2 \%)$ & $337(83,8 \%)$ \\
\hline Đã từng thực hiện xét nghiệm FOBT & $12(10,1 \%)$ & $26(9,2 \%)$ & $38(9,5 \%)$ \\
\hline Đã từng nội soi đại trực tràng & $11(9,2 \%)$ & $16(5,7 \%)$ & $27(6,7 \%)$ \\
\hline \multicolumn{4}{|c|}{ Lịch sử tham gia sàng lọc ung thư khác } \\
\hline Không & $108(90,8 \%)$ & $252(89,0 \%)$ & $360(89,6 \%)$ \\
\hline Có & $11(9,2 \%)$ & $31(11,0 \%)$ & $42(10,4 \%)$ \\
\hline
\end{tabular}

3.2. Kiến thức và thái độ của đối tượng đối với sàng lọc UTĐTT

Bảng 2 trình bày kết quả phân tích mô tả đối với một số biến số về kiến thức và thái độ của người dân đối với sàng lọc UTĐTT bao gồm đánh giá tầm quan trọng của các biện pháp dự phòng, nâng cao sức khỏe bao gồm tập thể dục, ăn nhiều hoa quả và rau, sàng lục ung thư cổ tử cung và ung thư vú với nữ giới dựa trên thang đo từ 1 đến 5 tương ứng với không quan trọng đến vô cùng quan trọng. Nhìn chung đối tượng đánh giá cao tầm quan trọng của tập thể dục, với điểm trung bình là $3,55(\mathrm{SD}=1,04)$ và của ăn nhiều hoa quả và rau, với điểm trung bình là $3,41(S D=0,99)$.

Khi được hỏi về mức độ lo lắng mình sẽ mắc UTĐTT thì cũng có tới 53,6\% nhóm đối tượng trên 60 tuổi trả lời là không hề lo lắng mình sẽ mắc UTĐTT. Tỷ lệ này ở nhóm 50-60 tuổi là $42,6 \%$. Tỷ lệ này ở nam giới $(47,9 \%)$ cũng thấp hơn ở nữ giới $(48,4 \%)$. Khi tự đánh giá về nguy cơ mắc UTĐTT thì có $27,6 \%$ đối tượng đánh giá có nguy cơ thấp hơn mọi người. Tỷ lệ này ở nhóm đối tượng trên 60 tuổi là cao nhất (chiếm tỷ lệ 32,9\%).

Đối với câu hỏi về lý do lớn nhất khiến người dân không chi trả tiền túi để sàng lọc sử dụng FOBT, có $78,0 \%$ đối tượng trả lời câuu hỏi này. Các lý do khi được phân vào các nhóm thì chủ yếu liên quan đến thiếu kiến thức $(39,3 \%)$, do các đối tượng đánh giá rằng người dân "không nghĩ mình có bệnh" hay "thiếu hiểu biết thông tin khám sàng lọc", "không biết về phương pháp này có thể sàng lọc được" hay "chỉ khi nào có biểu hiện bệnh thì mới đi khám". Có 6,5\% đối tượng cho rằng lý do lớn nhất khiến người dân không sàng lọc sử dụng FOBT liên quan đến quy trình lấy phân có thể không vệ sinh ("nghĩ làm xét nghiệm phân liên quan tới giun sán" hay "ngại làm xét nghiệm phân vì sợ bẩn"). Có $11,7 \%$ lý do liên quan đến sự sợ hãi của đối tượng, chẳng hạn như "sợ đi kiểm tra phát hiện ra bệnh lại lo nghĩ thêm", "sợ đến bệnh viện", "sợ làm phiền đến con cháu"... Có 14,2\% đối tượng lại đưa ra các rào cản về chi phí liên quan đển điều kiện kinh tế, đặc biệt ở nhóm người cao tuổi không đủ điều kiện kinh tế hoăc kinh tế phụ thuộc vào con cái và liên quan đển "lo lắng chi phí xét nghiêm cao". Chỉ có $3 \%$ đối tượng đưa ra các ý kiến khác như "cảm thấy kết quả không chính xác" và "người nhiều tuổi không cần thiết làm xét nghiệm".

Đối với cầu hỏi về lý do lớn nhất khiến người dân không chi trả để sàng lọc sử dụng nội soi đại trực tràng, cũng có $78,1 \%$ đối tượng trả lời cẩu hỏi này nhưng chỉ có $8,0 \%$ đối tượng đánh giá lý do lớn nhất là do thiếu kiến thức (nhu' "thây bản thân không có nguy cơ" hay "không biết đến nội soi đại trực tràng"). Đặc biết có đến 34,8\% đối tượng thể hiện lý do liên quan đến sự sợ hãi, bên cạnh "sợ hãi khi phát hiện ra bệnh" như ở trường hợp trên thì rất nhiều người có tâm lý "sợ gây mê", "sợ đưa dụng cụ vào cơ thể gây khó chịu" hay "sợ đau". Các rào cản về chi phí trong trường hợp này cũng được chỉ ra với tỷ lệ cao hơn nhóm trên "chi phí cao, tốn kém" hay "phải trả thêm phí gây mê đắt tiền". 
VIETNAM MEDICAL JOURNAL N01 - JUNE - 2021

Bảng 2: Kiến thức, và thái độ của đôî tượng đôî với sàng lọc UTĐTT

\begin{tabular}{|c|c|c|c|}
\hline & $\operatorname{Nam}(n=119)$ & $N \tilde{u}(n=283)$ & Chung ( $n=402)$ \\
\hline \multicolumn{4}{|c|}{ Đánh giá tâm quan trọng của tập thế dục } \\
\hline Trung bình (SD) & $3,63(1,10)$ & $3,52(1,00)$ & $3,55(1,04)$ \\
\hline Trung vị [Min, Max] & $4,00[1,00 ; 5,00]$ & $4,00[1,00 ; 5,00]$ & $4,00[1,00 ; 5,00]$ \\
\hline Không trả lời & $3(2,5 \%)$ & $29(10,2 \%)$ & $32(8,0 \%)$ \\
\hline \multicolumn{4}{|c|}{ Đánh giá tầm quan trọng của ăn nhiều hoa quả và rau } \\
\hline Trung bình (SD) & $3,42(1,06)$ & $3,40(0,97)$ & $3,41(0,99)$ \\
\hline Trung vị [Min, Max] & $4,00[1,00 ; 5,00]$ & $3,00[1,00 ; 5,00]$ & $4,00[1,00 ; 5,00]$ \\
\hline Không trả lời & $6(5,0 \%)$ & $33(11,7 \%)$ & $39(9,7 \%)$ \\
\hline \multicolumn{4}{|c|}{ Đánh giá tầm quan trọng của sàng lọc ung thư cố tử cung với nữ giới } \\
\hline Trung bình (SD) & $2,76(1,03)$ & $2,70(1,29)$ & $2,71(1,26)$ \\
\hline Trung vi [Min, Max] & $3,00[1,00 ; 5,00]$ & $3,00[1,00 ; 5,00]$ & $3,00[1,00 ; 5,00]$ \\
\hline Không trả lời & $86(72,3 \%)$ & $45(15,9 \%)$ & $131(32,6 \%)$ \\
\hline \multicolumn{4}{|c|}{ Đánh giá tầm quan trọng của sàng lọc ung thư vú với nữ giới } \\
\hline Trung bình (SD) & $2,83(1,05)$ & $2,71(1,33)$ & $2,73(1,30)$ \\
\hline Trung vị [Min, Max] & $3,00[1,00 ; 5,00]$ & $3,00[1,00 ; 5,00]$ & $3,00[1,00 ; 5,00]$ \\
\hline Không trả lời & $89(74,8 \%)$ & $42(14,8 \%)$ & $131(32,6 \%)$ \\
\hline \multicolumn{4}{|c|}{ Lo lằng mình sẽ măc UTĐTT } \\
\hline Không hề lo lắng & $57(47,9 \%)$ & $137(48,4 \%)$ & $194(48,3 \%)$ \\
\hline Có lo lắng một chút & $52(43,7 \%)$ & $123(43,5 \%)$ & $175(43,5 \%)$ \\
\hline Khá lo lắng & $9(7,6 \%)$ & $22(7,8 \%)$ & $31(7,7 \%)$ \\
\hline Cực kì lo lắng & $1(0,8 \%)$ & $1(0,4 \%)$ & $2(0,5 \%)$ \\
\hline \multicolumn{4}{|c|}{ Tự đánh giá về nguy cơ mắc UTĐTT } \\
\hline Thấp hơn mọi người & $30(25,2 \%)$ & $81(28,6 \%)$ & $111(27,6 \%)$ \\
\hline Như mọi người & $67(56,3 \%)$ & $152(53,7 \%)$ & $219(54,5 \%)$ \\
\hline Cao hơn mọi người & $10(8,4 \%)$ & $10(3,5 \%)$ & $20(5,0 \%)$ \\
\hline Không biết & $12(10,1 \%)$ & $40(14,1 \%)$ & $52(12,9 \%)$ \\
\hline \multicolumn{4}{|c|}{ Lý do lớn nhất khiến người dân không chi trả đế sàng lọc sử dụng FOBT } \\
\hline Thiếu kiến thức & $52(43,7 \%)$ & $106(37,5 \%)$ & $158(39,3 \%)$ \\
\hline Thấy không vệ sinh & $5(4,2 \%)$ & $21(7,4 \%)$ & $26(6,5 \%)$ \\
\hline Sợ hãi & $15(12,6 \%)$ & $32(11,3 \%)$ & $47(11,7 \%)$ \\
\hline Rào cản về thời gian & $5(4,2 \%)$ & $6(2,1 \%)$ & $11(2,7 \%)$ \\
\hline Rào cản về chi phí & $17(14,3 \%)$ & $40(14,1 \%)$ & $57(14,2 \%)$ \\
\hline Không được khuyến cáo & $2(1,7 \%)$ & $3(1,1 \%)$ & $5(1,2 \%)$ \\
\hline Khác & $3(2,5 \%)$ & $9(3,2 \%)$ & $12(3,0 \%)$ \\
\hline Không trả lời & $20(16,8 \%)$ & $66(23,3 \%)$ & $86(21,4 \%)$ \\
\hline \multicolumn{4}{|c|}{ Lý do lớn nhất khiến người dân không chi trả để sàng lọc sử dụng nội soi ĐTT } \\
\hline Thiếu kiến thức & $9(7,6 \%)$ & $23(8,1 \%)$ & $32(8,0 \%)$ \\
\hline Sợ hãi & $41(34,5 \%)$ & $99(35,0 \%)$ & $140(34,8 \%)$ \\
\hline Rào cản về thời gian & $5(4,2 \%)$ & $4(1,4 \%)$ & $9(2,2 \%)$ \\
\hline Rào cản về chi phí & $45(37,8 \%)$ & $87(30,7 \%)$ & $132(32,8 \%)$ \\
\hline Khác & $1(0,8 \%)$ & $2(0,7 \%)$ & $3(0,7 \%)$ \\
\hline Không trả lời & $18(15,1 \%)$ & $68(24,0 \%)$ & $86(21,4 \%)$ \\
\hline
\end{tabular}

3.3. Mối liên quan giữa kiến thức, thái độ đối với sàng lọc UTĐTT và từ chối chi trả đối với sàng lọc UTĐTT. Bảng 3 trình bày kết quả mô hình hồi quy logistic đa biến mô tả mối liên quan giữa biến phụ thuộc là từ chối chi trả (tạm dịch là $0=$ từ chối chi trả và $1=$ không từ chối chi trả (non-zero response) đối với sàng lọc UTĐTT và các biến số độc lập. Kết quả phân tích cho thây đối tượng sống trong hộ gia đình có nhiều thành viên hơn có xác suất không từ chối chi trả thấp hơn 0,75 lần so sánh với người sống trong hộ gia đình có ít thành viên hơn $(p<0,05)$; đối tượng đi khám bệnh cùng người thân có xác xuất không từ chối chi trả cao hơn 10,9 lần so sánh với đối tượng không đi khám bệnh cùng người thân $(p<0,05)$; người có lo lắng mình sẽ mắc ung thư đại trức tràng có xác suất không từ chối chi trả cao hơn 3,41 lần so sánh với người 
không hề lo lắng $(p<0,05)$; đối tượng đánh giá bản thân có nguy cơ mắc UTĐTT bằng hoặc cao hơn mọi người có xác suất không từ chối chi trả thấp hơn 0,1 lần nhóm tự đánh giá có nguy cơ thấp hơn mọi người $(p<0,05)$; nhóm ưa thích phương pháp nội soi đại trực tràng cũng có xác suất không từ chối chi trả thấp hơn 0,34 lần so sánh với nhóm ưa thích FOBT hoặc ưa thích hai phương pháp như nhau.

Bảng 3: Mô hình hồi quy logistic đa biến mô tả mối liên quan giữa biến phụ thuộc là từ chôi chi trả cho sàng lọc UTĐTT và các biến độc lập

\begin{tabular}{|c|c|c|c|c|c|c|}
\hline & Hê số & \multicolumn{2}{|c|}{ OR (95\%CI) } & SE & $\mathbf{Z}$ & $\mathbf{P}$ \\
\hline Tuối & $-0,0736$ & 0,93 & $(0,86 ; 1)$ & 0,0399 & $-1,84$ & 0,0654 \\
\hline Thu nhập & $-0,0002$ & 0,99 & $(0,99 ; 1)$ & 0,0001 & $-1,76$ & 0,0782 \\
\hline Nữ giới & $-0,0713$ & 0,93 & $(0,31 ; 2,81)$ & 0,5633 & $-0,13$ & 0,8993 \\
\hline Đã kết hôn & $-0,0563$ & 0,95 & $(0,07 ; 12,67)$ & 1,3241 & $-0,04$ & 0,9661 \\
\hline Có bảo hiểm y tế & $-0,2925$ & 0,75 & $(0,48 ; 1,17)$ & 0,2283 & $-1,28$ & 0,2003 \\
\hline Số thành viên trong hộ gia đình & $-0,2632$ & 0,77 & $(0,61 ; 0,97)$ & 0,119 & $-2,21$ & $0,0269 *$ \\
\hline Là người kiếm tiền chính trong gia đình & 0,5235 & 1,69 & $(0,54 ; 5,26)$ & 0,5804 & 0,9 & 0,3671 \\
\hline Có học vấn từ THPT trở lên & 0,375 & 1,45 & $(0,57 ; 3,72)$ & 0,4787 & 0,78 & 0,4335 \\
\hline Có bảo hiểm y tế & $-0,0057$ & 0,99 & $(0,09 ; 10,02)$ & 1,1789 & 0 & 0,9962 \\
\hline Có ít nhất 1 yếu tố nguy cơ & 0,8489 & 2,34 & $(0,79 ; 6,92)$ & 0,5538 & 1,53 & 0,1253 \\
\hline Người thân có ít nhất 1 yếu tố nguy cơ & 1,2687 & 3,56 & $(0,96 ; 13,24)$ & 0,6707 & 1,89 & 0,0586 \\
\hline Đi khám bệnh cùng người thân & 2,3857 & 10,9 & $(2,2 ; 53,67)$ & 0,8148 & 2,93 & $0,0034 * *$ \\
\hline Đã từng sàng lọc ung thư khác & $-0,5858$ & 0,56 & $(0,16 ; 1,89)$ & 0,6245 & $-0,94$ & 0,3482 \\
\hline Đã từng sàng lọc UTĐTT & $-0,8248$ & 0,44 & $(0,15 ; 1,29)$ & 0,5488 & $-1,5$ & 0,1329 \\
\hline Hiện tại đang làm việc & $-1,0617$ & 0,35 & $(0,1 ; 1,21)$ & 0,6398 & $-1,66$ & 0,097 \\
\hline Lo lắng mình sẽ mắc UTĐTT & 1,2268 & 3,41 & $(1,27 ; 9,18)$ & 0,505 & 2,43 & $0,0151^{*}$ \\
\hline $\begin{array}{l}\text { Đánh giá bản thân có nguy cơ mắc } \\
\text { UTĐTT bằng hoặc cao hơn mọi người }\end{array}$ & $-2,3407$ & 0,1 & $(0,02 ; 0,4)$ & 0,7223 & $-3,24$ & $0,0012 * *$ \\
\hline Ua thích phương pháp nội soi & $-1,086$ & 0,34 & $(0,13 ; 0,87)$ & 0,4824 & $-2,25$ & $0,0244 *$ \\
\hline
\end{tabular}
$\mathrm{N}=402 ; \mathrm{R} 2=0,378 ; \mathrm{AUC}=0,824 ;$ Brier $=0,047 ;$

**mức ý nghĩa thống kê 0,01 ; *mức ý nghĩa thống kê 0,05

\section{BÀN LUÂN}

Trong các rào cản được đối tượng chỉ ra trong việc chi trả tiền túi để thực hiện xét nghiệm FOBT, lý do phổ biến nhất được đưa ra không phải liên quan đến yếu tố khả năng chi trả mà là lý do liên quan đến kiến thức của người dân ("không nghĩ mình có bệnh" hay "thiếu hiểu biết thông tin khám sàng lọc", "không biết về phương pháp này có thể sàng lọc được" hay "chỉ khi nào có biểu hiện bệnh thì mới đi khám"). Lý do tiếp theo mới liển quan đến rào cản về chi phí với $14,2 \%$ ý kiến trả lời liên quan đến rào cản này, đặc biệt ở nhóm người cao tuổi không đủ điều kiển kinh tế hoắc kinh tế phụ thuộc vào con cái và liên quan đến "lo lắng chi phí xét nghiệm cao". Có một số lượng nhỏ (6,5\%) đối đượng đánh giá rào cản liên quan đến việc chi trả để thực hiện xét nghiệm FOBT là do người dân không sàng lọc sử dụng FOBT liên quan đến quy trình lây phân có thể không vệ sinh ("nghĩ làm xét nghiệm phân liên quan tới giun sán" hay "ngại làm xét nghiệm phân vì sợ bẩn").

Ngược lại, đối với nội soi đại trực tràng thì rào cản phổ biến nhất được chỉ ra lại liên quan đến sự "sợ hãi khi phát hiện ra bệnh", "sợ đến bệnh viện", "sợ gây mê", "sợ đưa dụng cụ vào cở thể gây khó chịu" hay "sợ đau" (34,8\%). Các rào cản về chi phí trong trường hợp này cũng được chỉ ra với tỷ lệ cao hơn so sánh với FOBT với các lý giải phổ biến như "chi phí cao, tốn kém" hay "phải trả thêm phí gây mê đắt tiền". Mặc dù không thực sự tương đồng nhưng một số nghiên cứu trên thế giới đã thực hiện về rào cản đối với người dân trong việc thực hiện xét nghiệm FOBT và nội soi đại trực tràng trong các chương trình sàng lọc UTĐTT nói chung cũng chỉ ra một số yếu tố tương tự (chẳng hạn sợ hãi, quá trình chuẩn bị khiến đổi tượng cảm thấy khó chịu, thiếu kiến thức, đau đớn và rào cản liên quan đến chi phí, các vấn đề khác đang hiện diện quan trọng hơn, thiếu khuyến cáo từ bác sỹ, không ưu tiên được thời gian để làm xét nghiệm [3-5]). Việc xem xét chi tiết các rào cản này cũng sẽ đóng vai trò quan trọng trong việc thiết kế được chương trình sàng lọc hiệu quả.

Kết quả phân tích hồi quy logistic đa biến được trình bày trong Bảng 3 cũng cho thây một số mối liên quan có ý nghĩa thống kê đến tỷ lệ từ 
chối chi trả tâp trung vào các biến số về kiến thức và thai độ của đối tượng. Chẳng hạn như đối tượng lo lắng mình sẽ mắc UTĐTT và đánh giá bản thân có nguy cơ mắc UTĐTT thấp hơn mọi người có xác suất từ chối chi trả cao hơn. Tuy nhiên, kết quả phân tích cũng cho thấy việc đối tượng lo lắng mình sẽ mắc UTĐTT có xác suất từ chối chi trả cao hơn. Đây là một kết quả tương đối đặc biệt. Tuy nhiên, điều này cũng có thể lý giải được thông qua việc xem xét các lý do trả lời của đối tượng trong nghiên cứu gốc đó là việc từ chối thực hiện sàng lọc do "sợ phát hiện ra bệnh". Kết quả của mô hình phân tích hồi quy logistic đa biến kể trên có thể cung cấp một số bằng chứng khẳng định cho vai trò của các kế hoạch truyền thông trong tương lai. Để cho chương trình sàng loc UTĐTT sử dụng FOBT và nội soi đại trực tràng thực sự có hiệu quả thì việc truyền thông nhằm tăng cường kiển thức và thái độ của đối tượng là vô cùng quan trọng nhẳm tăng cường số lượng đối tượng đích tiếp cận các kỹ thuật sàng lọc.

\section{KẾT LUÂ̂N}

Kiến thức của đối tượng ("không nghĩ mình có bệnh" hay "thiếu hiểu biết thông tin khám sàng lọc", "không biết về phương pháp này có thể sàng lọc được" hay "chỉ khi nào có biểu hiện bệnh thì mới đi khám") là rào cản phổ biến nhất $(43,7 \%)$ trong việc chi trả tiên túi để thực hiện xét nghiệm FOBT. Rào cản phổ biến nhất đối với chi trả tiền để nội soi đại trực tràng liên quan đến sự sợ hãi $(34,8 \%)$ ("sợ hãi khi phát hiện ra bệnh", "sợ đến bệnh viện", "sợ gây mê", "sợ đưa dụng cụ vào cơ thể gây khó chịu" hay "sợ đau"). Kiến thức và thái độ của đối tượng đối với UTĐTT được chỉ ra là có mối liên quan có ý nghĩa thống kê đối với tỷ lệ từ chối chi trả tiền túi để thực hiện sàng lọc UTĐTT. Các can thiệp nhằm cải thiện kiến thức của đối tượng đích đối xét nghiệm FOBT và thay đổi "sự sợ hãi" của đối tượng với với nội soi đại trực tràng là rất quan trọng nhằm cải thiện hiệu quả của các can thiệp sàng lọc UTĐTT trong tương lai.

\section{TÀI LIÊU THAM KHẢO}

1. Nguyễn Thanh Hương and L.N. KHuê, Gánh nặng bệnh tật và tuổi thọ khỏe mạnh: Khái niệm, phương pháp và kết quả của Việt Nam giai đọan 2008-2017. 2019.

2. Nguyễn Thu Hà and Nguyễn Quỳnh Anh, Báo cáo đề tài cấp cơ sở: Đánh giá mức sẵn sàng chi trả đối với mô̂t số can thiêp phát hiên sớm ung thư tại Việt Nam - Nghiên cứu trường hợp đối với Ung thư đại trực tràng. 2020, Trường Đại học $Y$ tế Công cộng: Hà Nội, Việt Nam.

3. Brouse, C.H., et al., Barriers to colorectal cancer screening with fecal occult blood testing in a predominantly minority urban population: a qualitative study. American journal of public health, 2003. 93(8): p. 1268-1271.

4. Javadzade, S.H., et al., Barriers related to fecal occult blood test for colorectal cancer screening in moderate risk individuals. Journal of education and health promotion, 2014. 3.

5. Jones, R.M., et al., Patient-reported barriers to colorectal cancer screening: a mixed-methods analysis. American journal of preventive medicine, 2010. 38(5): p. 508-516.

\section{THỰC TRANG ĐIỀU KIỆN LAO ĐộNG VÀ SỨC KHỎE CÔNG NHÂN NGÀNH MAY TẠI CÔNG TY TNHH HAIVINA KIM LIÊN, NGHỆ AN NĂM 2020}

\section{Hoàng Thị Giang1, Lê Tuấn $\mathrm{Anh}^{2}$, Vũ Hải Vinh ${ }^{3}$, Phạm Minh Khuêt}

\section{TÓM TẮT}

Nghiên cứu mô tả cắt ngang tiến hành tại Công ty TNHH Haivina Kim Liên, Nghệ An từ tháng 1 đến tháng 12 năm 2020 dựa trên cổng cụ đo đạc đánh giá

\footnotetext{
1 Trường Đại học Y Dược Hải Phòng

${ }^{2}$ Trung tâm Kiểm soát bệnh tật tỉnh Nghệ An

${ }^{3}$ Bệnh viện Hữu nghị Việt Tiệp, Hải Phòng

Chịu trách nhiệm chính: Hoàng Thị Giang

Email: hoangggiang0708@gmail.com

Ngày nhận bài: 9.3.2021

Ngày phản biên khoa học: 10.5.2021

Ngày duyệt bài: 18.5.2021
}

môi trường lao động và 1000 người lao động thuộc công ty nhằm mục đích đánh giá điều kiện lao động tại và tình trang sức khỏe bệnh tật của công nhân tại cơ sở này. Kết quả nghiên cứu cho thấy, về điều kiện lao động, 20/45 mấu đo nhiệt độ, 21/45 mấu đo độ ẩm, 18/45 mẫu đo tốc độ gió, 26/45 mẫu đo chiếu sáng, 6/45 mẫu đo tiếng ồn và 11/45 mẫu đo bụi bông không đạt tiêu chuẩn cho phép theo các tiêu chuẩn cho phép tại Việt Nam. Tỉ lệ người lao động có sức khỏe loại I, loại II chiếm tỉ lệ cao nhất với 86,9\%. Bệnh tật tai - mũi - họng và phế quản - phổi là những nhóm bệnh tật có tî lệ cao nhất trong cơ cấu bệnh tật của cổng nhân may tại đây, tỉ lệ lần lượt là $15,3 \%$ và $10,6 \%$. Tuổi nghề cao có ành hưởng đển tỉ lệ mắc các bệnh lí tai - mũi - họng, phế quản - phổi, 